\title{
Evidence of changes in renal charge selectivity in patients with Type 1 (insulin-dependent) diabetes mellitus
}

\author{
A. Kverneland ${ }^{1}$, B. Feldt-Rasmussen ${ }^{1}$, P. Vidal ${ }^{3}$, B. Welinder ${ }^{2}$, L. Bent-Hansen ${ }^{1}$, U. Søegaard ${ }^{1}$ and T. Deckert ${ }^{1}$ \\ ${ }^{1}$ Steno Memorial Hospital and ${ }^{2}$ Hagedorn Research Laboratory, Gentofte, Denmark; ${ }^{3}$ University of Santiago de Compostela, \\ Santiago de Compostela, Spain
}

\begin{abstract}
Summary. Altered filtration of macromolecules due to decreased electrical charge of the glomerular basement membrane might be the initial step in the development of albuminuria in patients with Type 1 (insulin-dependent) diabetes mellitus. We therefore investigated the selectivity index, i.e. renal clearance of non-glycated plasma albumin/clearance of glycated plasma albumin in 38 patients with Type 1 diabetes mellitus. The two albumin molecules differed slightly in charge, non-enzymatic glycated albumin being more anionic at physiological $\mathrm{pH}$ compared with unmodified plasma albumin. Glycated albumin in plasma and urine was determined by a specific, sensitive and highly reproducible chromatographic procedure. In diabetic patients with normal urinary albumin excretion, the selectivity index was increased threefold compared with that of non-diabetic subjects $(2 p<0.01)$. A significant correlation $(r=0.53,2 p<0.01)$ between haemoglobin $A_{1 \mathrm{c}}$ and selectivity index was demonstrated in these patients, indicating a change in charge-dependent renal filtration could possibly be attributed to non-enzymatic glycation of components in the glomerular basement membrane and tubuli. Diabetic patients with increased albumin excretion rate
\end{abstract}

had a significantly lower selectivity index compared with patients with normal albumin excretion $(2 p<0.01)$. A significant negative correlation $(r=0.85,2 p<0.001$, exponential curve fit) was seen between urinary albumin excretion and selectivity index in the diabetic patients, indicating that the capability of differentiating between macromolecules of different charges is again lost with increasing urinary albumin excretion.

In conclusion, the selectivity index is significantly increased in Type 1 diabetic patients with normal urinary albumin excretion, possibly due to non-enzymatic glycation of structural glomerular proteins. The selectivity index is again reduced with increasing urinary albumin excretion, possibly due to structural changes different from non-enzymatic glycation. This observation is in accordance with the hypothesis that loss of anionic charges due to reduced heparan sulphate content in glomerular basement membranes plays an important role in the early stages of diabetic renal disease.

Key words: Type 1 diabetes, selectivity index, glycated albumin, renal albumin clearance.
The structural alterations of glomerular basement membrane (GBM) leading to an increase of albumin excretion in the urine of patients with Type 1 (insulin-dependent) diabetes mellitus - the first clinical sign of diabetic nephropathy - are unknown. It has been hypothesized that an increase of urinary albumin excretion (UalbV) is related to alterations in cross linkage of GBM macromolecules induced by loss of anionic charges $[1,2]$. According to the hypothesis, a decrease of anionic charges of the glomerular filtration barrier in patients characterized by increasing UalbV would be expected to be accompanied by a gradual loss of the ability of nephrons to differentiate between unmodified and glycated plasma albumin, two endogenous macromolecules which differ slightly in anionic charge; non-enzymatic glycated albumin is more anionic at physiologic $\mathrm{pH}$ compared with unmodified plasma albumin $[3,4]$.

In order to test this hypothesis, we investigated the renal clearance of unmodified as well as glycated plasma albumin in patients with Type 1 diabetes and different albuminuric levels.

\section{Subjects and methods}

\section{Subjects}

Thirty-eight patients with Type 1 diabetes and a diabetes duration of more than three years were studied. They had no history of non-diabetic renal disease and all had a negative bacterial culture of urine. Nine normal non-diabetic persons with no history of renal disease or hypertension served as control subjects (group A). The diabetic pat- 
Table 1. Clinical data

\begin{tabular}{|c|c|c|c|c|c|c|c|c|c|c|}
\hline Group & $\begin{array}{l}\text { Sex } \\
(\mathrm{f} / \mathrm{m})\end{array}$ & $\begin{array}{l}\text { Age } \\
\text { (years) }\end{array}$ & $\begin{array}{l}\text { Diabetes }^{\mathrm{a}} \\
\text { duration } \\
\text { (years) }\end{array}$ & $\begin{array}{l}\mathrm{HbA}_{1 \mathrm{c}} \mathrm{b} \\
(\%)\end{array}$ & $\begin{array}{l}\text { Mean }^{c} \\
\text { BP } \\
(\mathrm{mmHg})\end{array}$ & $\begin{array}{l}\text { Se-creati- } \\
\text { nine } \\
(\mu \mathrm{mol} / 1)\end{array}$ & $\begin{array}{l}\text { Se-albumin } \\
(\mu \mathrm{mol} / \mathrm{l})\end{array}$ & $\begin{array}{l}\text { Urinary } \\
\text { albumin } \\
\text { excretion } \\
\text { nmol/1 }\end{array}$ & $\begin{array}{l}\text { Diurese } \\
\text { (1) }\end{array}$ & $\begin{array}{l}\text { Retinopathy } \\
0 / \text { simplex/ } \\
\text { proliferative }\end{array}$ \\
\hline $\begin{array}{l}\text { Group A } \\
\text { Normal control } \\
\text { subjects }(n=9)\end{array}$ & $2 / 7$ & $\begin{array}{c}33 \\
(31-44)\end{array}$ & - & $\begin{array}{c}5.3 \\
(4.4-5.7)\end{array}$ & $\begin{array}{c}93 \\
(87-103)\end{array}$ & $\begin{array}{c}86 \\
(71-105)\end{array}$ & $\begin{array}{c}657 \\
(598-732)\end{array}$ & $\begin{array}{c}84 \\
(29-104)\end{array}$ & $\begin{array}{c}1.62 \\
(0.85-4.95)\end{array}$ & - \\
\hline \multicolumn{11}{|l|}{ Group B } \\
\hline $\begin{array}{l}\text { Type } 1 \text { diabetic } \\
\text { patients }\end{array}$ & $11 / 12$ & 33 & 11.5 & 8.9 & 90 & 83 & 641 & 63 & 1.96 & $18 / 4 / 1$ \\
\hline $\begin{array}{l}\text { Urinary albumin } \\
\text { excretion } \\
<30 \mathrm{mg} / 24 \mathrm{~h} \\
(n=23)\end{array}$ & & $(18-51)$ & $(3-25)$ & $(6.2-11.1)$ & $(80-100)$ & $(68-100)$ & $(526-693)$ & $(37-269)$ & $(0.87-4.03)$ & \\
\hline $\begin{array}{l}\text { Group C } \\
\text { Type } 1 \text { diabetic } \\
\text { patients }\end{array}$ & $1 / 5$ & 28 & 22.5 & 7.6 & 96 & 83 & 582 & 1323 & 2.00 & $2 / 3 / 1$ \\
\hline $\begin{array}{l}\text { Urinary albumin } \\
\text { excretion } \\
30-300 \mathrm{mg} / 24 \mathrm{~h} \\
(n=6)\end{array}$ & & $(21-45)$ & $(15-28)$ & $(6.8-10.1)$ & $(88-113)$ & $(66-107)$ & $(507-701)$ & $(588-1529)$ & $(0.85-2.90)$ & \\
\hline \multicolumn{11}{|l|}{ Group D } \\
\hline $\begin{array}{l}\text { Type } 1 \text { diabetic } \\
\text { patients }\end{array}$ & $3 / 6$ & 32 & 17 & 10.1 & 107 & 90 & 490 & 5042 & 2.50 & $0 / 5 / 4$ \\
\hline $\begin{array}{l}\text { Urinary albumin } \\
\text { excretion } \\
>300 \mathrm{mg} / 24 \mathrm{~h} \\
(n=9)\end{array}$ & & $(25-51)$ & $(8-48)$ & $(6.2-12.3)$ & $(98-127)$ & $(58-429)$ & $(365-610)$ & $(764-25299)$ & $(1.40-11.6)$ & \\
\hline
\end{tabular}

Clinical data for the normal control subjects (group A) and the Type 1 diabetic patients (groups B, C and D). Results are given as median (range). ${ }^{a}$ Wilcoxon unpaired test: group B vs C $2 p<0.01$; group B vs D $2 p<0.02$; ${ }^{b}$ group C vs D $2 p<0.01$; ${ }^{\circ}$ group B vs D $2 p<0.01$; group B vs $\mathrm{C} 2 p=0.05 ;{ }^{\mathrm{d}}$ group B vs D $2 p<0.01$

ients were subdivided into three groups (B, C, D) according to the level of albuminuria (median UalbV in at least three $24 \mathrm{~h}$ urine collections performed at home during normal physical activity). Group B consisted of 23 patients with normal UalbV $(<30 \mathrm{mg} / 24 \mathrm{~h})$, group C comprised six patients with elevated UalbV $(30-300 \mathrm{mg} / 24 \mathrm{~h})$, and group D consisted of nine patients with clinical diabetic nephropathy (UalbV $>300 \mathrm{mg} / 24 \mathrm{~h}$ ).

All subjects gave their informed consent for participation. The clinical data are given in Table 1 . The patients in group B had a shorter duration of diabetes compared with groups $C$ and D. Patients in group $\mathrm{D}$ had higher $\mathrm{HbA}_{1 \mathrm{c}}$ levels compared with the other groups.

\section{Methods}

Glycated albumin was measured using the method described by Schleicher and Wieland [5] and modified for urinary albumin by Welinder et al. [6]. Briefly, urinary proteins were precipitated by $10 \%$ TCA, redissolved and dialyzed against $0.38 \mathrm{~mol} / 1$ ammonium bicarbonate at $4{ }^{\circ} \mathrm{C}$ and $\mathrm{pH}$ 7.5. Plasma and urinary albumin was isolated using affinity chromatography on Affigel Blue (BioRad, Richmond, Calif., USA). Disk electrophoresis showed that this procedure excluded all proteins other than albumin. Recovery during the urinary isolation procedure was tested by adding human serum albumin (HSA) as well as in-vitro glycated HSA to urine from a normal control subject. Identical recoveries of $75 \%$ were found for HSA and glycated HSA [6]. After the isolation procedure albumin was hydrolyzed under Argon in $6-\mathrm{N} \mathrm{HCl}$ at $110^{\circ} \mathrm{C}$ for $20 \mathrm{~h}$. The hydrolysis product of fructose-lysine, furosine, represents glycated lysine residues, whereas tyrosine represents total albumin, glycated as well as non-glycated; it was therefore used as internal standard. Furosine and tyrosine were measured by reversed phase high performance liquid chromatography (RP-HPLC) at wavelength $280 \mathrm{~nm}$ and $254 \mathrm{~nm}$ respectively. Assuming a molecular weight of urine and plasma albumin of 68,000 , each molecule containing 59 lysine and 18 tyrosine residues [7], the molar concentration of glycated and non-glycated albumin-derived lysine in urine and plasma was calculated. The concentration of albumin-derived glycated lysine was taken to be equivalent to glycated albumin, whereas the concentration of albumin-derived non-glycated lysine was taken to be equivalent to non-glycated albumin. The ratio between non-glycated albumin derived lysine clearance/glycated albumin-derived lysine clearance was expressed as selectivity index, SI. The interassay variation of serum and urine was 3.6 and $4.0 \%$, the intraassay variation of serum and urine 1.9 and 3.1 respectively.

Twenty-four hour urine collection was performed in plastic bags under normal daily conditions and delivered to the hospital the following morning. All urine samples were prepared within $24 \mathrm{~h}$ after being stored at $4^{\circ} \mathrm{C}$. At this temperature no non-enzymatic glycation occurs. Even at $20^{\circ} \mathrm{C}$ and $200 \mathrm{mmol}$ glucose $/ 1$ the amount of glycated albumin increased by only $1 \%$ per hour. At $37^{\circ} \mathrm{C}$ and in high urinary glucose concentrations $(200 \mathrm{mmol} / \mathrm{l})$ the glycated albumin was increased 3-5 times $/ 20 \mathrm{~h}$, dependent on $\mathrm{pH}$. There was no difference between patients with normal UalbV and those with increased UalbV as to glucosuria and urinary $\mathrm{pH}$. Only six patients in group $\mathrm{C}$ and $\mathrm{D}$ had urinary glucose concentration $>10 \mathrm{mmol} / \mathrm{l}$, and in these patients no correlation to high glycated urinary albumin values was found.

$\mathrm{HbA}_{1 \mathrm{c}}$ was measured by column chromatography [8], normal range $4.2-6.4 \%$, interassay variation $3.8 \%$.

Urinary and plasma albumin was measured using and ELISA assay [9], interassay variation $8.3 \%$.

Serum creatinine was measured by reaction rate kinetic principle eliminating pseudo-creatinines [10], interassay variation $2.5 \%$. 
Table 2. Glycated albumin in plasma and urine, renal clearance of non-glycated albumin and glycated albumin, Selectivity Index, SI (renal clearance of non-glycated albumin/clearance of glycated albumin) in 9 non-diabetic control subjects and 38 Type 1 diabetic patients characterized by different urinary albumin excretion rates

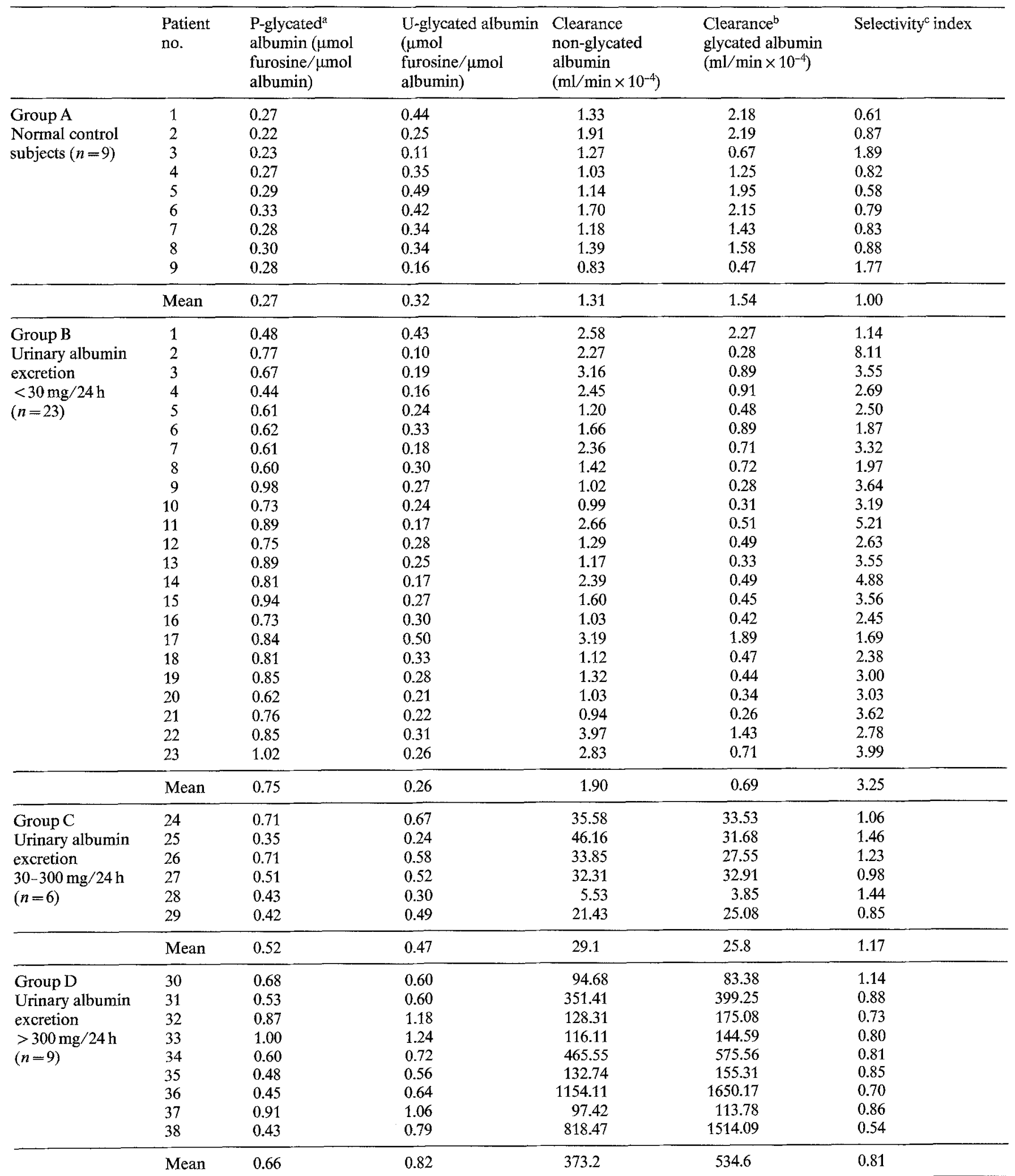

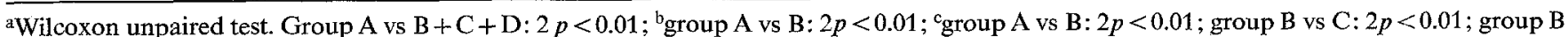
vs D: $2 p<0.01$; group A vs C: ns; group A vs D: ns; group C vs D: ns 


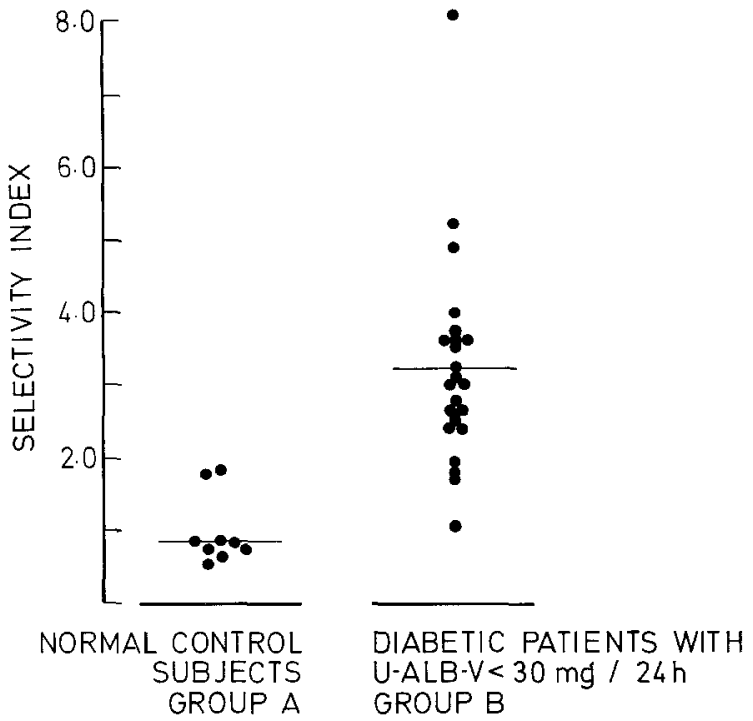

Fig. 1. Selectivity index (renal clearance of non-glycated albumin-derived lysine/renal clearance of glycated albumin-derived lysine) in normal control subjects $(n=9)$ and Type 1 diabetic patients with normal UalbV $(<30 \mathrm{mg} / 24 \mathrm{~h})(n=23)$

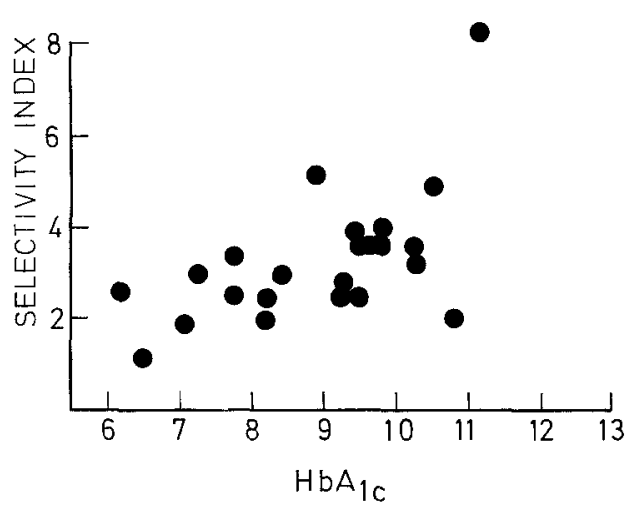

Fig. 2. Correlation between $\mathrm{HbA}_{1 \mathrm{c}}$ and selectivity index (SI) in 23 Type 1 diabetic patients with normal UalbV $(r=0.53,2 p<0.01)$

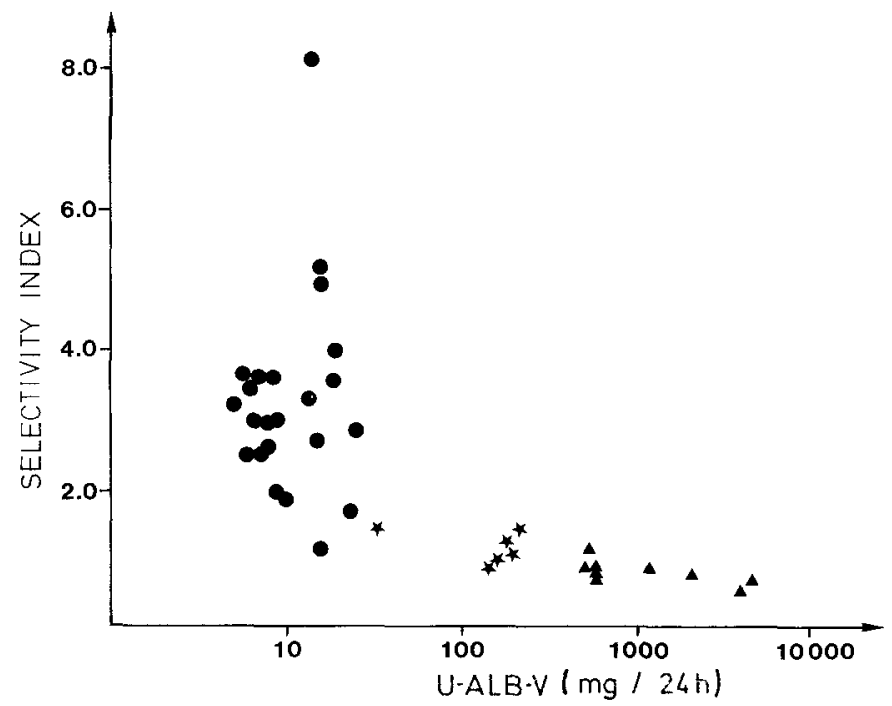

Fig. 3. Correlation between selectivity index (SI) and UalbV in Type 1 diabetic patients $(r=0.85,2 p<0.001$, exponential curve fit $) \cdot=$ Type 1 diabetes, UalbV $<30 \mathrm{mg} / 24 \mathrm{~h}(n=23) ; *=$ Type 1 diabetes, UalbV $30-300 \mathrm{mg} / 24 \mathrm{~h} \quad(n=6) ; \AA=T y p e 1$ diabetes, UalbV $>300 \mathrm{mg} / 24 \mathrm{~h}$ $(n=9)$

\section{Statistical analysis}

The Wilcoxon two sample test was used for comparison between the groups. Correlation was tested by linear regression analysis.

\section{Results}

The clinical data of the patients are shown in Table 1 . In patients with clinical diabetic nephropathy, i.e. albumin excretion $>300 \mathrm{mg} / 24 \mathrm{~h}$ and elevated blood pressure $(2 p<0.01)$, serum albumin was reduced $(2 p<0.01)$. Plasma albumin from control subjects contained about $0.27 \mu \mathrm{mol}$ glycated lysine per $\mu \mathrm{mol}$ plasma albumin (Table 2). The renal clearance of non-glycated albumin was similar to that of glycated albumin, resulting in a mean selectivity index of 1.0 (range $0.61-1.89$ ).

In diabetic patients the concentration of glycated plasma albumin ranged between about two- to threefold as high as in control subjects (Table 2). A significant correlation was found between glycated plasma albumin and $\mathrm{HbA}_{1 \mathrm{c}}(n=38, r=0.69,2 p<0.001)$.

The clearance of glycated albumin was significantly reduced in patients with normal UalbV (group B, $2 p<$ 0.01 ), whereas the clearance of non-glycated albumin was increased (ns), resulting in a three-fold increase of selectivity index Fig. 1. In these normoalbuminuric patients a significant correlation between $\mathrm{HbA}_{1 \mathrm{c}}$ and selectivity index ( $r=0.53,2 p<0.01$ ) was found (Fig. 2), suggesting that non-enzymatic glycation affects charge-dependent renal filtration. Correlation between selectivity index and diabetes duration was found in neither this group nor in the total group of diabetic patients.

In patients with increased UalbV (groups C and D) the renal clearance of glycated albumin increased more than clearance of non-glycated albumin, resulting in a significant decrease of selectivity index $(2 p<0.01)$ Table 2. Figure 3 demonstrates a significant negative correlation ( $r=0.85,2 p<0.001$, exponential curve fit) between UalbV and selectivity index in diabetic patients, suggesting that increasing UalbV is related to a decrease of renal anionic charge.

\section{Discussion}

We used a sensitive and reproducible method for the identification of glycated and non-glycated albumin in urine and serum. In contrast to the thiobarbituric acid method, our method is specific for the detection of ketoamine linkages of glycated proteins [5]. In order to avoid additional non-enzymatic glycation of albumin during collection and transportation, urine samples were stored at low temperature, where non-enzymatic glycation of albumin does not occur. Furthermore, the mean glucose concentration of the urine was low and similar in the diabetic groups, eliminating the influence of any additional glycation of the albumin which might 
have taken place in the urinary bladder. Assuming that only one lysine residue among the 59 lysine residues of human plasma albumin can undergo glycation, we found that $27 \%$ of the total plasma albumin was glycated in normal control subjects. This is in agreement with the findings of Schleicher and Wieland [5] using the same method. However, the calculated fraction of glycated plasma albumin depends on the number of lysine residues which are actually glycated in normoglycaemic persons, and this number is not exactly known [11]. In diabetic patients the plasma concentration of glycated albumin was more than twice as high. A significant correlation was found between $\mathrm{HbA}_{1 \mathrm{c}}$ and glycated plasma albumin in spite of different biological half-lives of these two proteins (17 and 3 weeks respectively). This correlation is in agreement with the observations made by others [12].

The renal clearance of glycated and non-glycated albumin was almost identical in normal control subjects, resulting in a mean selectivity index of 1.0 . In contrast, diabetic patients with normal UalbV demonstrated a significantly reduced clearance of glycated albumin combined with an increased clearance of non-glycated albumin, resulting in an increase of selectivity index to 3.25 (range 1.14-8.11). The increase of selectivity index in these normoalbuminuric diabetic patients might be explained by non-enzymatic glycation of components in the glomular basement membrane. If $\mathrm{HbA}_{1 \mathrm{c}}$ can be taken as an indication of the degree of glycation of components in the GBM, then the significant correlation between selectivity index and $\mathrm{HbA}_{1 \mathrm{c}}$ in patients of group $B$ supports this assumption. In the diabetic state several components of GBM, such as collagen IV [13] and fibronectin [14], have been found to undergo nonenzymatic glycation at lysine residues $[14,15]$. This glycation is expected to increase the anionic properties and alter the charge-dependent handling of macromolecules in the glomerular filtration barrier. Our observation of a reduced clearance of the more anionic glycated albu$\mathrm{min}$ in diabetic patients is in agreement with this hypothesis. We cannot exclude the possibility that the carbohydrate content of the glycated albumin molecule might facilitate filtration and/or reabsorption of these molecules [16], thus playing a role in the renal differentiation between glycated and non-glycated albumin. In our study, however, the clearance of glycated and nonglycated albumin were not significantly different in control subjects. The role played by tubular mechanisms is unknown, but the excretion of beta ${ }_{2}$-microglobulin as a marker of tubular function in uncomplicated diabetes mellitus is normal [18]. The increased selectivity index found in normoalbuminuric patients is hardly explained by increased tubular reabsorption of the more anionically charged glycated albumin, since an increased tubular reabsorption of cationic albumin has been demonstrated in rats [17]. Our results disagree with previous observations of a preferential urinary excretion of glycated protein in diabetic patients $[19,20]$. The method used by these authors for determination of glycated proteins was, however, less specific [5] and unreliable in our hands [6].

The ability of the nephrons to distinguish between glycated and non-glycated albumin was gradually lost in diabetic patients with elevated UalbV. In patients suffering from clinical nephropathy the selectity index was not significantly different from control subjects in spite of high $\mathrm{HbA}_{1 \mathrm{c}}$ levels, and thus high levels of glycation of structural protein. The cause of this decrease of SI in diabetic patients with increased UalbV is unknown, but is probably due to a gradual loss of anionic charges in the GBM unrelated to non-enzymatic glycation, since $\mathrm{HbA}_{1 \mathrm{c}}$ was similar in the groups.

Besides glycation of structural proteins, the anionic charge of normal GBM is attributed to the presence of carboxylated anions, glycosamine glycans (mainly heparan sulphate) and sialic acid [21-24]. The concentration of heparan sulphate in the GBM of diabetic patients with glomerulosclerosis is reduced [25], and it has been demonstrated that the de novo synthesis of sulphate rich proteoglycans is reduced in GBM of streptozotocin-diabetic rats $[26,27]$. Furthermore, Vernier recently demonstrated that the number of anionic sites in GBM from diabetic patients is negatively correlated to the albuminuric level (Vernier; personal communication, 1985). He was also able to demonstrate that these anionic sites were rich in heparan sulphate [28]. Thus, our finding of a negative correlation between selectivity index and UalbV could be explained by a reduction of the heparan sulphate units of the GBM in these patients. However, alterations in the content of sialic acid [29] and conformational processes related to advanced glycation products leading to loss of decarboxylatic acids in the GBM might also result in reductions of anionic charges and changes of charge-related handling of macromolecules.

In conclusion, selectivity index is significantly increased in Type 1 diabetic patients with normal urinary albumin excretion, possibly due to non-enzymatic glycation of structural glomerular proteins. The selectivity index is again reduced with increasing urinary albumin excretion, possibly due to structural changes different from non-enzymatic glycation. This observation is in accordance with the hypothesis that loss of anionic charges due to reduced heparan sulphate content in glomerular basement membranes plays an important role in the early stages of diabetic renal disease.

Acknowledgement. The authors are very grateful to Professor Wieland, Munich, for generously supplying us with furosine. The study was supported financially by Nordisk Insulinlaboratorium, Denmark.

\section{References}

1. Viberti G, Mackintosh D, Keen H (1983) Determinants of the penetration of proteins through the glomerular barrier in insulindependent diabetes mellitus. Diabetes 32 (Suppl 2): 92-95 
2. Deckert T, Feldt-Rasmussen B, Mathiesen ER, Baker L (1984) Pathogenesis of incipient nephropathy: a hypothesis. Diabetic Nephropathy $3: 83-88$

3. Day JF, Thorpe SR, Baynes JW (1979) Nonenzymatically glycosylated albumin. J Biol Chem 254: 595-597

4. Ghiggeri GM, Candiano G, Delfino G, Queirolo C (1985) Electrical charge of serum and urinary albumin in normal and diabetic humans. Kidney Int 28: 168-177

5. Schleicher E, Wieland OH (1981) Specific quantitation by HPLC of protein (Lysine) bound glucose in human serum albumin and other glycosylated proteins. J Clin Chem Clin Biochem 19: 81-87

6. Welinder BS, Vidal P, Deckert T, Hansen B (1985) Estimation of glycosylated albumin in serum and urine. Diabetes Res Clin Pract Suppl I: 599

7. Dayhoff MO (1978) Atlas of protein sequence and structure 5 (Suppl 3): 306. National Biomedical Research Foundation, Georgetown University Medical Center, Washington D.C.

8. Svendsen P Aa, Christiansen JS, Søegaard U, Welinder BS, Nerup J (1980) Rapid changes in chromatographically determined haemoglobin $A_{1 c}$ induced by short-term changes in glucose concentration. Diabetologia 19:130-136

9. Feldt-Rasmussen B, Dinesen B, Deckert M (1985) Enzyme immunoassay: an improved determination of urinary albumin in diabetics with incipient nephropathy. Scand J Clin Lab Invest 45: $539-544$

10. Larsen K (1972) Serum-creatinine. Clin Chim Acta 41:209-217

11. Shaklai N, Garlick RL, Bunn HF (1984) Nonenzymatic glycosylation of human serum albumin alters its conformation and function. J Biol Chem 259: 3812-3817

12. Dolhofer R, Wieland OH (1980) Increased glycosylation of serum albumin in Diabetes Mellitus. Diabetes 29:417-422

13. Cohen MP, Urdanivia E, Surma M, Wu VY (1980) Increased glycosylation of glomerular basement membrane collagen in diabetes. Biophys Res Commun 95: 765-69

14. Tarsio JF, Wigness B, Rhode TD, Rupp WM, Buchwald H, Furcht LT (1985) Nonenzymatic glycation of fibronectin and alterations of cell matrix and basement membrane components in diabetes mellitus. Diabetes 34: 477-484

15. Schober E, Pollak A, Coradello H, Lubec G (1982) Glycosylation of glomerular basement membrane in type 1 (insulin-dependent) diabetic children. Diabetologia 23: 485-487

16. Williams SK, Siegal KS (1985) Preferential transport of non-enzymatically glycosylated ferritin across the kidney glomerulus. Kidney Int 28: 146-152

17. Christensen EI, Rennke HG, Carone FA (1983) Renal tubular uptake of protein: effect of molecular charge. Am J Physiol 244: F436-F441
18. Mathiesen ER, Oxenbøll B, Johansen K, Svendsen P Aa, Deckert $T$ (1984) Incipient nephropathy in type 1 (insulin-dependent) diabets. Diabetologia 26: 406-410

19. Ghiggeri GM, Candiano G, Gerolamo D, Queirolo C (1985) Electrical charge of serum and urinary albumin in normal and diabetic humans. Diabetologia 28: 168-177

20. Gragnoli G, Signorini AM, Tanganelli I (1984) Nonenzymatic glycosylation of urinary proteins in type 1 (insulin-dependent) diabetes: correlation with metabolic control and the degree of proteinuria. Diabetologia 26: 411 414

21. Brenner BM, Hostetter TH, Humes HD (1978) Molecular basis of proteinuria of glomerular origin. N Engl J Med 298: 826-33

22. Farquhar MG (1981) The glomerular basement membrane. In: Hay ED (ed) Cell biology of extracellular matrix. Plenum Press, New York, London, pp 335-378

23. Kanwar YS (1984) Biology of disease. Biophysiology of glomerular filtration and proteinuria. Lab Invest 51: 7-21

24. Bray J, Robinson GB (1984) Influence of charge on filtration across renal basement membrane films in vitro. Kidney Int 25: $527-533$

25. Parthasarathy N, Spiro RG (1982) Effect of diabetes on glycosaminoglycan component of the human glomerular basement membrane. Diabetes 31: 738-741

26. Kanwar YS, Rosenzweig LJ, Linker A, Jakubowski L (1983) Decreased de novo synthesis of glomerular proteoglycans in diabetes: biochemical and autoradiographic evidence. Proc Natl Acad Sci 80: 2272-2275

27. Cohen MP, Surma ML (1984) Effect of diabetes on in vivo metabolism of $\left({ }^{35} \mathrm{~S}\right)$-labeled glomerular basement membrane. Diabetes 33: $8-12$

28. Vernier RL, Klein DJ, Sisson SP, Mahan JD, Oegema TR, Brown DM (1983) Heparan sulfate-rich anionic sites in the human glomerular basement membrane. N Engl J Med 309: 1001-1009

29. Wahl P, Deppermenn D, Hasslacher C (1982) Biochemistry of glomerular basement of the normal and diabetic human. Kidney Int 21:744-749

Received: 5 February 1986

and in revised form: 5 July 1986

Dr. Arne Kverneland

Steno Memorial Hospital

2, Niels Steensens Vej

DK-2820 Gentofte

Denmark 